\title{
指数関数型非線形構成則に従う一次元棒における 応力波伝播挙動の厳密な解析
}

\section{A mathematical analysis for stress wave propagation of a cylindrical bar with the constitutive equation represented by an exponential function}

\author{
Tomonori WATANABE*1 \\ ${ }^{* 1}$ Graduate School of Engineering, Chiba University \\ 1-33 Yayoi-cho, Inage-ku, Chiba-shi, Chiba 263-8522, Japan
}

Received 19 May 2014

\begin{abstract}
We have theoretically investigated the properties of the stress wave propagation which is caused by a longitudinal impact of a cylindrical bar by a one-dimensional model. In the present study, the effects of the boundary condition and material nonlinearity of the bar are taken into account. An exponential function is chosen as the constitutive equation in order to realize that the one-dimensional model possesses some useful properties for the analysis. A governing equation which describes the behaviors of the stress wave is derived from the one-dimensional model. Since the governing equation is complicated, some mathematical techniques are applied in order to analyze the behaviors of the stress wave. As a result, it is shown that the stress wave, which can propagate through the cylindrical bar of semi-infinite length and that of finite length, is derived exactly from the governing equation. Moreover, the behaviors of the stress wave are shown analytically.
\end{abstract}

Key words : Stress wave, Nonlinear problem, Constitutive equation, Numerical analysis, Computational mechanics, Exact solution

1. 緒言

衝撃荷重下での材料や構造物の力学的挙動を明らかにすることは，工学上重要な問題である. 近年では，安心 · 安全への関心の高まりともあいまって, 衝撃荷重下での材料や構造物の力学的挙動の解明に向けた様々な研究が 活発になされている. とりわけ基本的であり, 実用上も重要である一次元棒を対象とした研究では, 実験的観点 からは, Split Hopkinson Pressure Bar 法や One bar 法など, 種々の衝撃試験法が考案され, それらの試験によって 得られた実験データが広く産業界にて活用されてきている（Johnson, 1972, 谷村, 1997）。一方, 理論的観点か らは，一次元弾性波伝播理論をはじめ，塑性波伝播を取り扱った Karman 理論（Karman and Duwez，1950）など によって，衝撃荷重下での応力波の伝播解析について多くの重要な知見が得られている.

一般に, 衝撃荷重下での材料や構造物の力学的挙動は, 準静的な挙動と比べて高速であり，さらに，応力が波と して伝播し, 反射や干渉などが生じるために振舞いが複雑となり，取り扱いが非常に困難になることが知られて いる（Johnson，1972，谷村，1997）。特に，構成則が非線形性を有する場合において，反射波などを生じる境界 条件も含めて応力波の伝播挙動を取り扱うことは, 理論的観点からは, 種々の衝撃試験法での結果や, spalling 破 壊などの特徵的な現象を理解するうえでも非常に重要であるにもかかわらず，大変困難なものとなっている．それ ゆえ, 現在では, 数值計算による応力波伝播の解析が有効な方法のひとつとなっている. しかし, 数值計算にお

No.14-00265 [DOI: 10.1299/transjsme.14-00265], J-STAGE Advance Publication date : 10 December, 2014

*1 正員, 千葉大学大学院工学研究科人工システム科学専攻（† 263-8522 千葉県千葉市稲毛区弥生町 1-33）

E-mail of corresponding author: nabe@faculty.chiba-u.jp 
いても, 有限桁の数を取り扱うがゆえに結果は誤差を含んだものとなり, 特に, 非線形系を取り扱う場合には, カ オスの発生など, 本来予期せ女結果が得られることもあり, 妥当性と信頼性のある結果を得るためには細心の注 意を払わなくてはならないことが知られている（渡辺，2010b）。それゆえ，たとえ特殊な場合における解であっ ても, 対象とする系に対する厳密な解を得ておくことは, 妥当性と信頼性のある数值計算を行う上で, 保証と指 針を与えることが可能となるため，有効なアプローチのひとつであると考えられる.

そこで, 本研究では, 構成則が非線形性を有する一次元棒を対象に, 境界条件も含めて応力波の伝播挙動の厳 密な解析方法を明らかにすることを目的とする. そのために, 本研究では, 近年発達してきた種々の新たな数理 的手法を応用する. 特に, 指数関数型の構成則を用いることで, 系に数值計算上有用で顕著な特徴を付与させる ことが可能となることを明らかにした前報（渡辺, 2010a，2010b）の結果を活用し, 本研究でも, 非線形性を有 する構成則として, 指数関数型の構成則を応用する.

次章では, まず, 一次元棒の典型的なモデルに指数関数型構成則を応用し, 本研究での基礎方程式を導出する. つぎに, 第 3 章では, 本研究での基礎方程式をもとに, 代表的な境界条件を課した一次元棒として無限長棒, 半 無限長棒, および, 有限長棒を取り上げ, それぞれの棒における応力波の伝播挙動について数理的な検討を行う. 最後に, 第 4 章に, 本研究での結論を述べる.

\section{2. 指数関数型構成則と基礎方程式}

本章では, 一次元棒の典型的なモデルに非線形性を有する構成則として, 指数関数型構成則を応用し, 本研究 にて取り扱う基礎方程式を導出する. なお，本研究では，微小変形理論が成立する範疇を主な対象とする.

一次元棒を伝播する波の挙動を考える. 棒の密度 $\rho$ は一定とする. 棒の軸方向に $x$ 軸をとり, 時刻 $t$ のときの 位置 $x$ での変位と応力をそれぞれ, $u(x, t)$, および, $\sigma(x, t)$ とすると, 運動方程式は,

$$
\rho \frac{\partial^{2} u(x, t)}{\partial t^{2}}=\frac{\partial \sigma(x, t)}{\partial x}
$$

となる(Johnson, 1972)．ここで，ひずみを，

$$
\varepsilon(x, t):=\frac{\partial u(x, t)}{\partial x}
$$

と定義する.つぎに, 構成則を導入するために, 時間 $t$ は連続変数のままとし, 空間変数について, 数值計算など による解析の際での典型的な手法である変数の離散化を行なう. すなわち, 軸方向の位置 $x$ につて, 離散間隔 $l$ にて空間離散化を行い, 任意の整数 $n$ を用いて, $x=n l$ とし, 離散変数を

$$
\sigma_{n}(t):=\sigma(n l, t), \quad \varepsilon_{n}(t):=\varepsilon(n l, t),
$$

とおき, 式(1)において, 両辺を $x$ にて微分をした後に, 右辺の中心差分をとることにより, 空間離散化をした方 程式として,

$$
\rho \frac{\mathrm{d}^{2} \varepsilon_{n}(t)}{\mathrm{d} t^{2}}=\frac{1}{l^{2}}\left\{\sigma_{n+1}(t)-2 \sigma_{n}(t)+\sigma_{n-1}(t)\right\}
$$

を得る.この式が, 一次元棒の典型的なモデルの運動方程式となる.

以上のようにして得た運動方程式 (4) に対し, 本研究では, 前報（渡辺, 2010b）にならい, 指数関数型構成則 を応用する. すなわち, 運動方程式 (4) に対して, 構成則がもつ非線形性の影響を考慮するために, 一次元棒の応 力ーひずみ特性として,

$$
\sigma=a\{1-\exp (-b \varepsilon)\}+c
$$

を用いるものとする. ただし, $a, b$, および, $c$ は定数とする. このような構成則は, 従来の様々な研究において も広く用いられており, 実際に, たとえば, Voce 則（Voce，1948，1955）などとも同一視することができる.

このように, 本研究では, 前報 (渡辺, 2010b) と同じく, 一次元棒の典型的なモデルに指数関数型構成則を応 用したモデルを構成則が非線形性を有する一次元棒のモデルとして取り扱うものとする.ここで, 本研究の趣旨 
は, 運動方程式の普遍的な特徵を考察することにあるので, 空間離散化をした運動方程式 (4) に指数関数型構成則 (5) を用いた方程式について，規格化としての変数変換 :

$$
V_{n}(t):=-\frac{\sigma_{n}(t)-c}{a}, \quad \tilde{t}:=\sqrt{\frac{a b}{\rho l^{2}}} t,
$$

を行なったのちに，次章以降での取り扱いの便宜上，改めて， $\tilde{t}$ を $t$ として書き表した方程式：

$$
\frac{\mathrm{d}^{2}}{\mathrm{~d} t^{2}} \log \left\{1+V_{n}(t)\right\}=V_{n+1}(t)-2 V_{n}(t)+V_{n-1}(t),
$$

を，本研究での基礎方程式として取り扱うものとする．また，以後の考察のために，規格化をした変数として，粒 子位置と呼ばれる変位を表す変数 $q_{n}(t)$ を導入し,

$$
q_{n}(t):=\frac{1}{l} u(n l, t), \quad \varepsilon_{n}(t)=\frac{1}{b}\left\{q_{n}(t)-q_{n-1}(t)\right\},
$$

とする.

基礎方程式 (7) は，非線形偏差分方程式に分類される。非線形偏差分方程式では，一般的な解法は知られていな いのが現状である.しかし，そのような非線形偏差分方程式のひとつである式 (7) について, 本研究では, 種々の 数理的解析手法を応用し, 例外的に, 解の振舞いが得られることを明らかにし, これにより, 応力波の伝播挙動を 明らかにする。

\section{3. 結 果と考察}

\section{$3 \cdot 1$ 無限長棒}

\subsection{1 基礎方程式の変数変換}

境界条件のもとで基礎方程式 (7) の厳密解を得るために, 数理的工夫（Hirota，2004）として, 方程式 (7) に対 する変数変換を行う. 実際に, 変数変換として, 従属变数変換 $: V_{n}(t) \rightarrow \tau_{n}(t) ;$

$$
V_{n}(t)=\frac{\tau_{n+1}(t) \tau_{n-1}(t)}{\tau_{n}(t)^{2}}-1,
$$

を行うと，方程式：

$$
\frac{\mathrm{d}^{2} \tau_{n}(t)}{\mathrm{d} t^{2}} \tau_{n}(t)-\left\{\frac{\mathrm{d} \tau_{n}(t)}{\mathrm{d} t}\right\}^{2}=\tau_{n+1}(t) \tau_{n-1}(t)+h(t) \tau_{n}(t)^{2}
$$

を得ることができる.ただし， $h(t)$ は，初期条件等によって決まる任意の関数とする．以後にて明らかになるよう に, 式 (9) の変数変換を行い, 基礎方程式 (7) を方程式 (10)のように書き換えることが, 本研究での数理的解析上 の大きな特徵となる.

\subsection{2 無限長棒を伝播する孤立波}

本項では, 無限長棒における基礎方程式 (7) の解の例として, 衝撃荷重下での応力波の中でも重要な波のひとつ である孤立波を変数変換をした方程式(10) を用いて求める.

まず，もとの基礎方程式 (7) が自明な解 $V_{n}(t) \equiv 0$ を満たす場合を考える.このとき，方程式 (10)にて自明な解 に対応する解 $\tau_{n}(t) \equiv 1$ が存在するための条件として,

$$
h(t) \equiv-1,
$$

を得ることができる.

つぎに, 式(11)のもとで, 数理的解析手法（Toda, 1976）を応用し, 式 (10) の厳密解のひとつとして $\tau$ を,

$$
\tau_{n}(t)=1+\exp \{2(k n-\omega t+\theta)\},
$$

として求めると, 基礎方程式 (7)の厳密解として,

$$
V_{n}(t)=\sinh ^{2} k \operatorname{sech}^{2}(k n-\omega t+\theta),
$$




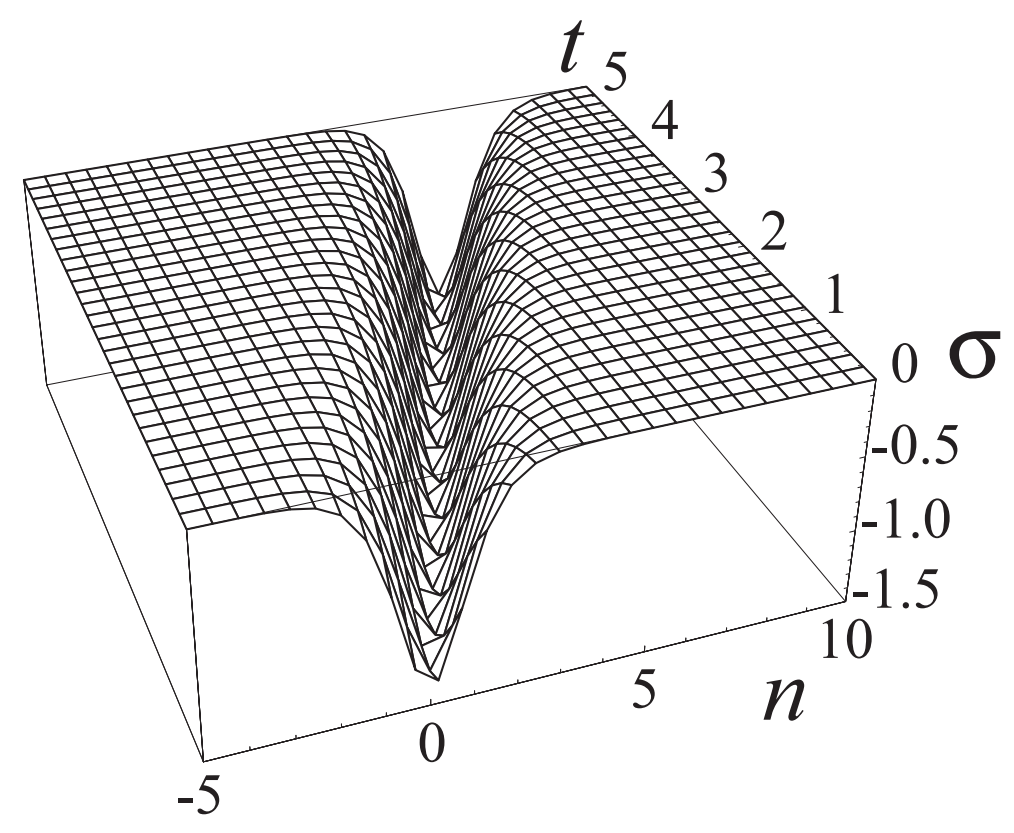

Fig. 1 Stress wave propagation by equation (14) for $a=1, c=0, k=1$ and $\theta=0$.

を得ることができる.さらに，変換式 (6) を用いると，

$$
\sigma_{n}(t)=c-a \sinh ^{2} k \operatorname{sech}^{2}(k n-\omega t+\theta),
$$

を得ることができる.ただし，ここで， $k$ は波数を意味する任意の定数であり, 周波数 $\omega$ は, 式 (12) が式 (10) を 満たすための条件から得られる定数である. また， $\theta$ は任意の定数とする. 式(12)を式 (10) に代入すると, $k$ と $\omega$ が,

$$
\omega= \pm \sinh k
$$

を満たす時に，式(12) は式(10) の解となることを確かめることができ，式 (15) が，分散関係式となることがわか る. 式(14)において, $a=1, c=0, k=1$, および， $\theta=0$ とした場合での振舞いを図 1 に示す. 図から, 式 (14) は, 圧縮の応力波に相当する孤立波をあらわし, 時間の経過とともに減衰や発散をすることなく安定に伝播する 特徵をもつことがわかる.

\section{$3 \cdot 2$ 半無限長棒}

\subsection{1 半無限長棒での基礎方程式の厳密解}

半無限長棒をあらわす境界条件として, 基礎方程式 (7)において, 位置 $n=0$ を一次元棒の左端とし, $n \geq 0$ の 領域を取り扱うものとする. 具体的には, 境界条件を, 粒子位置 $q_{n}(t)$ を用いて表すと, 後述のとおり, $q_{n}(t)$ を用 いた運動方程式 (60) において, 左端である $q_{0}(t)$ については,

$$
\frac{\mathrm{d}^{2} q_{0}(t)}{\mathrm{d} t^{2}}=-\exp \left\{q_{0}(t)-q_{1}(t)\right\}
$$

とおき, $n \geq 1$ での $q_{n}(t)$ については式 (60) を用いるものとする.このとき, 変換式である式 (6) や式 (9) などから 得られる $q_{n}$ と $\tau_{n}$ との直接的な関係式:

$$
\exp \left\{-q_{n}(t)\right\}=\frac{\tau_{n+1}(t)}{\tau_{n}(t)},
$$

を考慮すると，境界条件を表す式(16)，および，方程式(10)において $n=1$ とおいた式とを用いて，

$$
h(t)=\frac{\mathrm{d}^{2}}{\mathrm{~d} t^{2}} \log \tau_{0}(t)
$$


という関係を得ることができる.つぎに，この $h(t)$ のとで，変数 $T_{n}(t)$ を,

$$
T_{n}(t):=\frac{\tau_{n}(t)}{\tau_{0}(t)},
$$

と定義して，方程式 (10) を書き直すと，

$$
\frac{\mathrm{d}^{2} T_{n}(t)}{\mathrm{d} t^{2}} T_{n}(t)-\left\{\frac{\mathrm{d} T_{n}(t)}{\mathrm{d} t}\right\}^{2}=T_{n+1}(t) T_{n-1}(t),
$$

という式を得ることができる．この式において，独立変数 $n$ に着目すると，式 (20) は, $n$ についての漸化式になっ ていることがわかる.すなわち, これまでの変数変換式を考慮すると, 初項と第二項が,

$$
T_{0}=\frac{\tau_{0}}{\tau_{0}}=1, \quad T_{1}(t)=\frac{\tau_{1}(t)}{\tau_{0}(t)}=\exp \left\{-q_{0}(t)\right\}
$$

となり, $n \geq 1$ において, $T_{n+1}(t)$ が, $T_{n-1}(t)$ と $T_{n}(t)$ によって

$$
T_{n+1}(t)=\frac{1}{T_{n-1}(t)}\left[\frac{\mathrm{d}^{2} T_{n}(t)}{\mathrm{d} t^{2}} T_{n}(t)-\left\{\frac{\mathrm{d} T_{n}(t)}{\mathrm{d} t}\right\}^{2}\right],
$$

として与えられることがわかる。これにより, 逐次 $T_{n}(t)$ を計算することができ, 境界条件を表す式 (16) のもとで の応力波の伝播挙動を導出することができる.

さらに，近年明らかになった新たな数理手法（Kajiwara, et al., 2007）を応用すると, 方程式 (20), および, 漸化 式 (22) は直接的に厳密に解くことができる. 実際に, 計算によって一般項を求めると, $T_{n}(t)$ を, 行列式を用いて,

$$
T_{n}(t)=\left|\begin{array}{cccc}
T_{1}(t) & \frac{\mathrm{d}}{\mathrm{d} t} T_{1}(t) & \cdots & \frac{\mathrm{d}^{n-1}}{\mathrm{~d}^{n-1} t} T_{1}(t) \\
\frac{\mathrm{d}}{\mathrm{d} t} T_{1}(t) & \frac{\mathrm{d}^{2}}{\mathrm{~d}^{2} t} T_{1}(t) & \cdots & \frac{\mathrm{d}^{n-2}}{\mathrm{~d}^{n-2} t} T_{1}(t) \\
\vdots & \vdots & \cdots & \vdots \\
\frac{\mathrm{d}^{n-1}}{\mathrm{~d}^{n-1} t} T_{1}(t) & \frac{\mathrm{d}^{n-2}}{\mathrm{~d}^{n-2} t} T_{1}(t) & \cdots & \frac{\mathrm{d}^{2 n-2}}{\mathrm{~d}^{2 n-2} t} T_{1}(t)
\end{array}\right|,
$$

として得ることができる. 事実, この式が, 式 (20) と式 (22)を満たすことは, 代入をして確かめることができる. この結果を用いると, 応力波の伝播挙動をあらわすそれぞれの変数は, 逐次的にではなく, 直接的に得ることが できる.たとえば, 実際に, 粒子位置 $q_{n}(t)$ を求めると, 式 (23) を用いて,

$$
q_{n}(t)=\log \frac{T_{n}(t)}{T_{n+1}(t)},
$$

として得ることができる. よって, 式 (23) が, 半無限長棒を伝播する応力波をあらわす厳密解となる. なお, 次 項では, 本項の結果から得られる解のいくつかの具体例を明らかにする.

本項での結果から, 主として以下の二つの特徵がわかる. 第一には, 非線形偏差分方程式である基礎方程式 (7) の厳密解を半無限長棒という境界条件のもとで得ているということである. 上述のとおり, 一般に非線形方程式 の厳密解を得ることは非常に難しい.このような現状に対し, 指数関数型構成則 (5) と数理分野での研究成果を応 用することによって厳密解を具体的に得た本研究の結果は, 諸言で述べた通り, 厳密な解析が難しい非線形系を境 界条件つきで取り扱わなくてはならない場合に対し，有用な基礎的知見を与えることができるものと考えられる.

第二には，基礎方程式 (7) の解を得る方法について, 漸化式 (22) を用いて逐次的に得る方法と式 (23) を用いて 直接的に得る方法の二通りの方法を明らかにしているということである. 同じ解を与えるために，二通りの方法を 得たというこの結果は, 数值計算の観点からすると, 計算方法の選択の幅が拡がることを意味すると考えられる. すなわち, 漸化式 (22) を用いて逐次的に解を得る方法は, 数值計算においては繰り返し計算に適しており, 一方, 行列式を用いる式 (23) は, 数式処理システムに適していると考えられ, 数值計算上の状況に合わせた適切な計算 を行うことが可能になると考えられる. また, 従来の典型的な解析方法では, 運動方程式 (7) のみを解析対象とす るのに対し, 本研究での解析過程を応用すると, たとえば, 数理的な工夫によって得られた方程式 (20) など, 取 り扱う方程式として, 運動方程式 (7) に加え, 精度の観点などから適切な解を得るために適した方程式を選択する ことも可能となる. このように, 計算方法の選択の幅が拡がるということは, 高効率化や高精度化など数值解法 の性能の向上にもつながるものと考えられる. 


\subsection{2 半無限長棒を伝播する波の具体例}

本項では, 前項にて得た厳密解をもとに, 具体例として, 代表的な以下の三つの場合の結果のみを簡単に記す. まず，第一番目としては，左端 $n=0$ での境界条件として，粒子位置 $q_{0}(t)$ を,

$$
q_{0}(t)=-\frac{1}{2} t^{2},
$$

として与えた場合を考える．この場合について，第 3·2·1 項の結果を用いると，

$$
q_{n}(t)=\log \frac{\exp \left(-\frac{1}{2} t^{2}\right)}{n !},
$$

を得ることができ，ひずみとして，

$$
\varepsilon_{n}(t)=-\log n,
$$

を得ることができる.

つぎに，第二番目として，左端 $n=0$ での境界条件として，粒子位置 $q_{0}(t)$ を,

$$
q_{0}(t)=1-\exp (t),
$$

として与えた場合を考える。この場合について厳密解をもとめると，

$$
q_{n}(t)=\log \frac{\exp \{1-\exp (t)-n t\}}{n !},
$$

を得ることができ，ひずみとして，

$$
\varepsilon_{n}(t)=-t-\log n,
$$

を得ることができる.

最後に, 第三番目として, 左端 $n=0$ での境界条件として, 粒子位置 $q_{0}(t)$ を,

$$
q_{0}(t)=1-\exp (-t)
$$

として与えた場合を考える。この場合では，厳密解として，

$$
q_{n}(t)=\log \frac{\exp \{1-\exp (-t)+n t\}}{n !},
$$

を得ることができ，ひずみとして，

$$
\varepsilon_{n}(t)=t-\log n,
$$

を得ることができる.

上記の各解が，方程式や境界条件を満たすことは，実際に代入をして確かめることができる.

\section{$3 \cdot 3$ 有限長棒}

\subsection{1 有限長棒での基礎方程式の厳密解}

有限長棒をあらわす境界条件として, 基礎方程式 (7)において, 位置 $n=0$ を一次元棒の左端, および, 位置 $n=N$ を右端とし， $0 \leq n \leq N$ の領域を取り扱うものとする. ただし， $N$ は正の整数とする. 境界条件としては, 左端 $n=0$ については半無限長棒の場合である第 $3 \cdot 2$ 節での取り扱いと同じとし, さらに加えて, 右端である位置 $n=N$ についても, 左端と同じく, 後述のとおり, $q_{n}(t)$ を用いた運動方程式 $(60)$ において,

$$
\frac{\mathrm{d}^{2} q_{N}(t)}{\mathrm{d} t^{2}}=\exp \left\{q_{N-1}(t)-q_{N}(t)\right\},
$$

とおき， $1 \leq n \leq N-1$ での $q_{n}(t)$ については式 (60) を用いるものとする. 
以上のような境界条件のもとで応力波の伝播挙動を得るために, 半無限長棒の場合である第 3.2 節での結果を 応用する. すなわち, 方程式 (20), もしくは, 漸化式 (22) を新たに加わった右端での境界条件を表す式 (34) のも とで解くことを考える. そのために, 近年の数理分野での研究成果を応用する（Kajiwara, et al., 2007）. 実際に, 研究成果を応用し, 応力波の伝播挙動を厳密に得るための計算を行うと, $i=1, \cdots, N$, として, $c_{i}$ と $\mu_{i}$ を任意の 定数とし,

$$
T_{1}(t)=\sum_{i=1}^{N} c_{i} \exp \left(\mu_{i} t\right)
$$

とおくと，方程式 (20), および，漸化式 (22) の一般項として，式 (23) から，

$$
\begin{aligned}
& T_{n}(t)=\operatorname{det}(A B), \\
& A:=\left(\begin{array}{cccc}
c_{1} & c_{2} & \cdots & c_{N} \\
c_{1} \mu_{1} & c_{2} \mu_{2} & \cdots & c_{N} \mu_{N} \\
\vdots & \vdots & \cdots & \vdots \\
c_{1} \mu_{1}^{n-1} & c_{2} \mu_{2}^{n-1} & \cdots & c_{N} \mu_{N}^{n-1}
\end{array}\right), \quad B:=\left(\begin{array}{cccc}
\mathrm{e}^{\mu_{1} t} & \mu_{1} \mathrm{e}^{\mu_{1} t} & \cdots & \mu_{1}^{n-1} \mathrm{e}^{\mu_{1} t} \\
\mathrm{e}^{\mu_{2} t} & \mu_{2} \mathrm{e}^{\mu_{2} t} & \cdots & \mu_{2}^{n-1} \mathrm{e}^{\mu_{2} t} \\
\vdots & \vdots & \cdots & \vdots \\
\mathrm{e}^{\mu_{N} t} & \mu_{N} \mathrm{e}^{\mu_{N} t} & \cdots & \mu_{N}^{n-1} \mathrm{e}^{\mu_{N} t}
\end{array}\right),
\end{aligned}
$$

を得ることができる.この式 (36) が, 有限長棒を伝播する応力波をあらわす厳密解となる. 実際に, 式 (36) が解 であることは, 方程式 (20), もしくは, 漸化式 (22) に代入をして確かめることができる. また, 式 (36) が本項で の境界条件をみたすことは, 実際に代入をして確かめることができる. したがって, 式 (36) は, 有限長棒での解 であることがわかる。

以上の結果において, 注意すべきは, 式 (35) での定数 $c_{i}$ と $\mu_{i}$ は, 複素数を仮定していないということである. したがって, 式 (35) は, 指数関数の和として与えられてはいるが, Fourier 級数とは異なり, 物理的挙動としては, いわゆる振動モードの重ね合わせではなく，線形系での典型的な振舞いとは異なるものをあらわしているという ことがわかる.このことは, 基礎方程式 (7) を本項での境界条件にて解析する場合において, 非線形性の影響があ らわれる大きな特徵のひとつとなっている.

\subsection{2 有限長棒を伝播する孤立波}

本項では, 数理分野での研究結果（Nakamura，1998）を応用して, 具体例として, 実際に, 有限長棒を伝播す る孤立波の振舞いを明らかにする.

有限長棒をあらわす境界条件の一般化として， $M_{1}$ と $M_{2}$ をそれぞれ正の整数として，基礎方程式 (7)において， 位置 $n=-M_{1}-1$ を一次元棒の左端, および, 位置 $n=M_{2}$ を右端とし, $-M_{1}-1 \leq n \leq M_{2}$ の領域を取り扱うもの とする.この境界条件のもとで, $-M_{1}-1 \leq n \leq M_{2}$ にて, 関数 :

$$
v_{n}(t)=\left(n+M_{1}+1\right)\left(M_{2}-n\right) \frac{\alpha^{2} \exp (\alpha t+\beta)}{\{1+\exp (\alpha t+\beta)\}^{2}}-1,
$$

を考えると，

$$
V_{n}(t)=v_{n}(t)
$$

は，基礎方程式 (7) を満たす厳密解であることがわかる. ただし，ここで， $\alpha$ と $\beta$ は任意の定数とする．このよう に, 基礎方程式 (7) は, 境界条件のもとで多様な解を有していることがわかる.

以下では, 有限長棒の境界条件を満たす式 (38) を応用して新たな解を構成することを考える.すなわち, 基礎 方程式 (7) の新しい解 $V_{n}(t)$ を, 関数 $v_{n}(t)$ に加えて関数 $f_{n}(t)$ を用いて,

$$
V_{n}(t)=v_{n}(t)+\frac{\mathrm{d}^{2}}{\mathrm{~d}^{2} t} \log f_{n}(t)
$$


とする.このようにして $v_{n}(t)$ をもとにして新たな解を定め, 計算を行うと, 最終的に, 関数 $f_{n}(t)$ を,

$$
f_{n}(t)=1+\varepsilon^{2} \sum_{m=-M_{1}}^{n} A_{m} F\left(m-M_{2}, \bar{b} ;-M_{1}-M_{2} ; z\right)^{2} \times z^{-\left(M_{1}+M_{2}\right)}(z-1)^{m+\bar{b}+M_{1}},
$$

とおいた場合に，式 (40) は，基礎方程式 (7) を満たすことがわかる. ただし，ここで，Gauss の超幾何関数 $F$ を

$$
F(\bar{a}, \bar{b} ; \bar{c} ; z)=1+\frac{\bar{a} \bar{b}}{\bar{c} 1 !} z+\frac{\bar{a}(\bar{a}+1) \bar{b}(\bar{b}+1)}{\bar{c}(\bar{c}+1) 2 !} z^{2}+\cdots,
$$

とし， $\varepsilon$ と $\bar{b}$ を任意の定数として,

$$
A_{m}:=\frac{M_{1} ! M_{2} !}{\left(M_{1}+m\right) !\left(M_{2}-m\right) !}, \quad z:=1+\exp (\alpha t+\beta), \quad f_{-M_{1}-1}(t) \equiv 1,
$$

とした．以下では，第 $3 \cdot 1 \cdot 2$ 項にて明らかにした無限長棒を伝播する孤立波との比較を行うために，圧縮の応力波 に対象をしぼり, さらに, 物理的要請として, 次項にて述べる通り, 一次元棒の長さを有限から無限にする極限 において, 有限長棒と無限長棒での孤立波の振舞いに整合性をもたせるために, 実際に計算を行って妥当性を調 べることによって， $\bar{b}, \alpha ， お よ ひ ゙ ， \varepsilon$ の各定数を適切に定めた場合を考えるものとする．すなわち，具体的には， 式(41)において, $\bar{b} \equiv 0$ とした,

$$
f_{n}(t)=1+\varepsilon^{2} \sum_{m=-M_{1}}^{n} A_{m} z^{-\left(M_{1}+M_{2}\right)}(z-1)^{m+M_{1}},
$$

を取り扱い，定数 $\alpha$ と定数 $\varepsilon$ を，それぞれ，

$$
\alpha=\left(M_{1} M_{2}\right)^{-1 / 2}\{\exp (\beta / 2)+\exp (-\beta / 2)\},
$$

および,

$$
\varepsilon^{2}=(1+\exp \beta)^{\left(M_{1}+M_{2}\right)} \exp \left(-M_{1} \beta\right),
$$

とした場合について考察を行うものとする.

有限長棒を伝播する孤立波の振舞いとして, 両端において $\sigma=0$ となる境界条件にて, 初期条件を式 (38) と式 (44)において, $M_{1}=10, M_{2}=10$, および, $\beta=2$ とし， $\alpha$ とにには, それぞれ, 式(45) と式(46)を用いた場合に おいて, 式 (44) のもとでの解 (40) を変換式 (6) を用いて応力波の振舞いとしてあらわしたものを図 2 に示す. こ の図から, 式(38)のもとで, 圧縮の孤立波が時間とともに伝播していく様子がわかる. ただし, 孤立波の振幅に 着目すると, 図 1 での無限長棒の場合と比べて孤立波の振幅は時間とともに変化することがわかる.このことに ついては, 次項にて, 有限長棒と無限長棒との関係を明らかにした上で, 考察を加えるものとする.

\subsection{3 無限長棒を伝播する孤立波との関係}

本項では, 有限長棒の系がもつ性質として, 前項にて求めた式 (44) のもとでの式 (40) が, 無限長棒における孤 立波である式 (13) とどのような関係にあるのかを明らかにし, 妥当性を検証する. そのために, 一次元棒の長さ を有限から無限にする極限を考える.すなわち, 有限長棒から無限長棒への極限移行として, 有限長棒の境界にか かわる $M_{1}$ と $M_{2}$ について無限大の極限をとる場合を考えるものとする.このような極限移行にあたっては, 意味 のある極限を得るために, 定数 $\alpha$ と定数 $\varepsilon$ を, 前項にて示した式 (45), および, 式 (46) として定め, さらに, $M_{1}$ と $M_{2}$ に, 定数 $\gamma$ を用いて,

$$
\frac{M_{2}}{M_{1}}=\exp \gamma
$$

という関係を満足させながら, 極限として, $M_{1} \rightarrow+\infty$, をとるものとする. このような極限操作のもとで, 式 (40) を構成する式 (38) と式 (44) についての考察を行う.

まず，式 (38)については，実際に計算をすると，

$$
\lim _{M_{1} \rightarrow+\infty} v_{n}(t)=-1,
$$


となり，無限長棒では一様な引張状態を表すことがわかる.

つぎに，式(44)については,

$$
\lim _{M_{1} \rightarrow+\infty} A_{m}=\left(\frac{M_{2}}{M_{1}}\right)^{m}=\exp (\gamma m),
$$

となり,また，

$$
\lim _{M_{1} \rightarrow+\infty} \varepsilon^{2} z^{-\left(M_{1}+M_{2}\right)}(z-1)^{m+M_{1}}=\exp \left[\beta m-\left\{\exp \left(\frac{\beta+\gamma}{2}\right)-\exp \left(-\frac{\beta+\gamma}{2}\right)\right\} t\right],
$$

となるので, $f_{n}(t)$ として

$$
\lim _{M_{1} \rightarrow+\infty} f_{n}(t)=1+\sum_{m=-\infty}^{n} \exp \left[(\beta+\gamma) m-\left\{\exp \left(\frac{\beta+\gamma}{2}\right)-\exp \left(-\frac{\beta+\gamma}{2}\right)\right\} t\right],
$$

を得ることができる.この式において，

$$
k=\frac{\beta+\gamma}{2}, \quad \omega=\sinh k,
$$

とおくと, 式(51) は, $M_{1} \rightarrow+\infty に て$,

$$
f_{n}(t)=1+\sum_{m=-\infty}^{n} \exp (2 k m-2 \omega t)
$$

と書くことができる.ここで，式中の和を計算して簡単化するために，

$$
\theta=-\frac{1}{2} \log \{1-\exp (-2 k)\},
$$

とおくと, 最終的に,

$$
f_{n}(t)=1+\exp \{2(k n-\omega t+\theta)\},
$$

を得ることができる，この式は，無限長棒を伝播する孤立波をあらわす式(12) と一致する．また，式 (52) は，分 散関係式である式(15) と一致する. よって, 式(44) のもとでの式(40) は，無限長棒における孤立波である式 (13) と, 一次元棒の長さを無限大にする極限で一致し, ともに，圧縮の応力波をあらわすことがわかる.

したがって, 一次元棒の長さを無限大にする極限で孤立波の振舞いが一致するという本項での結果と, 図 2 に おいて，有限長棒での孤立波の振幅が，図 1 での無限長棒での場合と比べて時間とともに変化するという前項で の結果を考慮すると，境界の存在は孤立波の振幅の時間変化に影響をもたらすということがわかる.

また, 分散関係式が, 一次元棒の長さを無限大にする極限において, 式 (52)にて与えられることから, 空間離 散化をした運動方程式 (4)に構成則として Hookeの法則を用いた場合のように, 分散関係式が,

$$
\omega= \pm \sin k,
$$

として与えられるような典型的な場合と比べて，孤立波の伝播速度は大きく異なるものであることがわかる．こ のことは, 第 3.3.1 項にて述べたことと同様に, 構成則の非線形性の影響があらわれる大きな特徵であることがわ かる.

\subsubsection{Hamilton 系としての性質}

有限長棒の系がもつ物理的特徵のひとつとして, 数値計算への応用を想定し, Hamilton 系としての性質を明ら かにする.

基礎方程式 (7)について, 無次元化した運動量 $p_{n}$ を,

$$
p_{n}(t):=\frac{\mathrm{d}}{\mathrm{d} t} q_{n}(t)
$$

と定義し, Hamiltonian $\mathscr{H}$ を,

$$
\mathscr{H}:=\sum_{n}\left\{\frac{1}{2} p_{n}^{2}+\exp \left(q_{n}-q_{n+1}\right)-\left(q_{n}-q_{n+1}\right)-1\right\},
$$




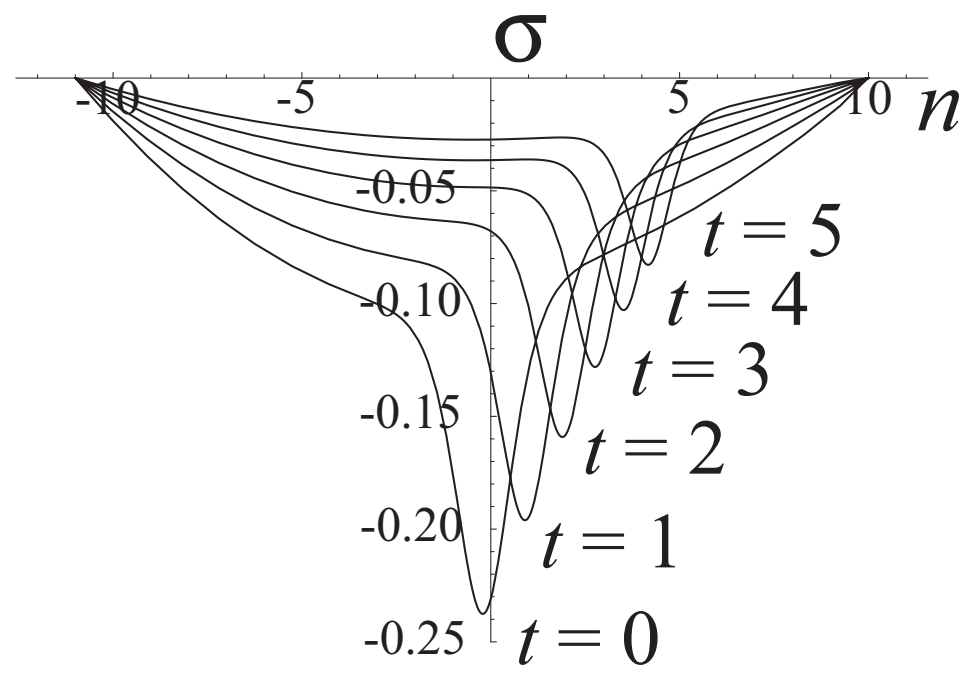

Fig. 2 Stress wave propagation by equation (44) for $M_{1}=10, M_{2}=10$ and $\beta=2$.

として与えると，基礎方程式 (7) の系は，Hamilton 系であることがわかる．実際に，Hamilton 系であることは，正 準方程式；

$$
\frac{\mathrm{d} q_{n}}{\mathrm{~d} t}=\frac{\partial \mathscr{H}}{\partial p_{n}}, \quad \frac{\mathrm{d} p_{n}}{\mathrm{~d} t}=-\frac{\partial \mathscr{H}}{\partial q_{n}},
$$

を計算することによって得られる運動方程式：

$$
\frac{\mathrm{d}^{2} q_{n}}{\mathrm{~d} t^{2}}=\exp \left(q_{n-1}-q_{n}\right)-\exp \left(q_{n}-q_{n+1}\right)
$$

が，変数変換 $(8)$ と構成則 (5) によって基礎方程式 (7) に等しくなることから確認することができる.

ここで，重心での位置 $Q(t)$ と運動量 $P(t)$ を表す物理量を，それぞれ，

$$
Q(t):=\frac{1}{N} \sum_{i=0}^{N-1} q_{i}(t), \quad P(t):=\frac{\mathrm{d}}{\mathrm{d} t} Q(t),
$$

として導入する。 いま, 本研究における有限長棒での境界条件を表す式である式 (16) と式 (34) に加え, 式 (24), 式(35), 式(36), および，式(60)を考慮すると， $Q(t)$ と $P(t)$ を,

$$
Q(t)=-\frac{1}{N} \log T_{N}(t), \quad P(t)=\frac{1}{N} \sum_{i=0}^{N-1} \mu_{i},
$$

として得ることができる.ここで，まず，位置 $Q(t)$ について，式 (36)において, $n=N$ の場合として，

$$
T_{N}(t)=\prod_{1 \leq i<j \leq N}\left(\mu_{i}-\mu_{j}\right)^{2} \prod_{i=1}^{N} c_{i} \exp \left(\mu_{i} t\right)
$$

となることを考慮すると, 重心での位置 $Q(t)$ は等速直線運動をすることがわかる.また, 運動量 $P(t)$ は定数とな り運動量が保存されることがわかる.したがって, これらの結果から, 有限長棒を解析する際には, 重心座標系 として, 変数変換 :

$$
\tilde{q}_{i}:=q_{i}-Q, \quad \tilde{p}_{i}:=p_{i}-P,
$$

を行うと, それぞれの変数について，

$$
\sum_{i=0}^{N-1} \tilde{q}_{i}=0, \quad \sum_{i=0}^{N-1} \tilde{p}_{i}=0,
$$


となる顕著な特長があることがわかる.このような特長は, 数值計算の観点からは, 結果の妥当性の確認や, 計 算の高効率化などを検討する際に役立てられるものと考えられる.

Hamilton 系は, たとえば, 有効な数值計算法のひとつである Symplectic 法（Yoshida，1993）と深いつながりを 持つ. Symplectic 法は, 原則的に, Hamilton 系を対象とした専用数值計算法であり, 系を長時間安定に計算させ ることができるという特長をもつ.したがって, 本項での結果は, 衝撃荷重下での応力波の伝播解析に Symplectic 法を援用する場合などにも役立てることができるものと考えられる.

\section{4. 結言}

本研究では, 構成則が非線形性を有する一次元棒を対象とし, 代表的な境界条件の下での応力波の伝播挙動に ついて, 数理的観点から検討を行った. 本研究にて得られた主な結果を以下に示す.

(1) たとえ構成則の非線形性と境界条件を考慮しなくてはならない場合であっても, 構成則に指数関数型構成則 を用いることで, 応力波の伝播挙動を数理的にあらわに得ることが可能となることを明らかにした.

(2) 一次元棒における応力波の伝播挙動をあらわす運動方程式から, 本研究での基礎方程式として非線形偏差分 方程式を導出し，この方程式を実際に各境界条件のもとで解き，厳密解を得た。

（3）各境界条件のもとでの厳密解をもとに具体例を示し, 応力波の振舞いを明らかにした. 特に, 境界の存在は 孤立波の振幅の時間変化に影響をもたらすことを明らかにした。さらに，系のもつ種々の性質を数理的に明 らかにした。

緒言でも述べたとおり, 一般に, 衝撃負荷を受ける材料や構造物の変形は, 現象が高速であるがゆえに実験での 取り扱いや制御が容易ではない.また, 理論においても, 構成則の非線形性を考慮しなくてはならない場合には, 解析は非常に困難なものになるとされている.このような状況において, 境界条件も含めて数理的に厳密な解析 方法を明らかにした本研究の結果は, 構成則に指数関数型構成則を応用することによってはじめて得ることがで きたものであり, たとえ限定的な特別な解であったとしても, 決して自明ではなく, 有用な基礎的知見が得られる ものであると考えられる.

文献

Hirota, R., The Direct Method in Soliton Theory (2004), Cambridge University Press.

Johnson, W., Impact Strength of Materials (1972), Edward Arnold.

Kajiwara, K.,Mazzocco, M. and Ohta, Y., A remark on the Hankel determinant formula for solutions of the Toda equation, Journal of Physics A, Vol.40 (2007), pp.12661-12675.

Karman, T. V. and Duwez, P., The propagation of plastic deformation in solids, Journal of Applied Physics, Vol.21 (1950), pp.987-994.

Nakamura, A., Explicit N-soliton solutions of the 1+1 dimensional Toda molecule equation, Journal of the Physical Society of Japan, Vol.67 (1998), pp.791-798.

谷村眞治, 材料・構造物の衝撃問題研究:これまでの推移と今後の展望, 日本機械学會論文集 A 編, Vol.63, No.616 (1997), pp.2466-2471.

Toda, M., Development of the theory of a nonlinear lattice, Supplement of the Progress of Theoretical Physics, Vol.59 (1976), pp.1-35.

Voce, E., The relationship between stress and strain for homogeneous deformation, Journal of the Institute of Metals, Vol.74 (1948), pp.537-562.

Voce, E., A practical strain-hardening function, Metallurgia, Vol.51 (1955), pp.219-226.

渡辺知規, 材料非線形性を有する一次元棒における応力波伝播解析へのセルオートマトンの応用, 日本機械学會 論文集 A 編, Vol.76, No.766 (2010a), pp.761-769.

渡辺知規, 衝撃荷重をうける一次元棒の応力波伝播解析への指数関数型構成則の応用, 日本機械学會論文集 $\mathrm{A}$ 編, Vol.76, No.767 (2010b), pp.893-901.

Yoshida, H., Recent progress in the theory and application of symplectic integrators, Celestial Mechanics and Dynamical Astronomy, Vol.56 (1993), pp.27-43. 


\section{References}

Hirota, R., The Direct Method in Soliton Theory (2004), Cambridge University Press.

Johnson, W., Impact Strength of Materials (1972), Edward Arnold.

Kajiwara, K.,Mazzocco, M. and Ohta, Y., A remark on the Hankel determinant formula for solutions of the Toda equation, Journal of Physics A, Vol.40 (2007), pp.12661-12675.

Karman, T. V. and Duwez, P., The propagation of plastic deformation in solids, Journal of Applied Physics, Vol.21 (1950), pp.987-994.

Nakamura, A., Explicit N-soliton solutions of the 1+1 dimensional Toda molecule equation, Journal of the Physical Society of Japan, Vol.67 (1998), pp.791-798.

Tanimura, S., Dynamic problems of materials and structures, Transactions of the Japan Society of Mechanical Engineers, Series A, Vol.63 (1997), pp.2466-2471 (in Japanese).

Toda, M., Development of the theory of a nonlinear lattice, Supplement of the Progress of Theoretical Physics, Vol.59 (1976), pp.1-35.

Voce, E., The relationship between stress and strain for homogeneous deformation, Journal of the Institute of Metals, Vol.74 (1948), pp.537-562.

Voce, E., A practical strain-hardening function, Metallurgia, Vol.51 (1955), pp.219-226.

Watanabe, T., Numerical analysis for stress wave propagation of a cylindrical bar with material nonlinearity by cellular automaton, Transactions of the Japan Society of Mechanical Engineers, Series A, Vol.76, No.766 (2010a), pp.761769 (in Japanese).

Watanabe, T., Numerical analysis for a longitudinal impact of a cylindrical bar with the constitutive equation represented by an exponential function, Transactions of the Japan Society of Mechanical Engineers, Series A, Vol.76, No.767 (2010b), pp.893-901 (in Japanese).

Yoshida, H., Recent progress in the theory and application of symplectic integrators, Celestial Mechanics and Dynamical Astronomy, Vol.56 (1993), pp.27-43. 